Jurnal Bimbingan Konseling
$10(1)(2021): 49-53$
UNNES

\title{
The Effectiveness of Life Skill Education-Based Digital Content to Improve Student Career Planning
}

\author{
Haris Yuftika Hani ${ }^{1 凶}$, Mulawarman Mulawarman ${ }^{2}$, Mungin Eddy Wibowo $^{2}$ \\ ${ }^{1 .}$ SMA Negeri 1 Bulakamba Brebes, Indonesia \\ 2. Universitas Negeri Semarang, Indonesia
}

\begin{abstract}
Article Info
History Articles

Received:

20 January 2021

Accepted:

27 February2021

Published:

30 April 2021

Keywords:

Digital Content, Life

skills education, career

Abstract

Career planning is one of important skill aspects taught to students through various methods. Most counselors tend to apply face to face method to teach it. Meanwhile, due to COVID-19 pandemic this method is truly difficult to be applied. For this reason, this studyattempted to examine the effectiveness of life skill education-based digital content to improve students' career planning by involving 150 students. The results of analysis showed that students' career planning successfully improved after the implementation of career guidance through life skill education-based digital content applied $(t=-189.37, p=0.01)$. Based on the results, life skill education based digital content is highly recommended to improve career planning in this COVID-19 pandemic.
\end{abstract}

planning

Correspondence address:

Gedung Pascasarjana UNNES, Jalan Kelud Utara III Semarang (50237)

E-mail: haniharisyuftika15@gmail.com 


\section{INTRODUCTION}

One of tasks of adolescent development is having an ability to prepare future career. High school students at least must have this ability to understand their interest and skill to be explored to face their future. Regarding career, high school students must begin to determine future career direction so they will pass the transition phase of career readiness to pursue higher level education or from school to work. For that reason, students need to get service in school including career guidance to prepare their future career. Career guidance is defined as a process of leading and providing students understanding about career so they are able to develop their future in line with their skill, interest, and desire (Astuti \& Purwanta, 2019).

Parson in Winkel \& Hastuti (2010) formulate a career planning as a way to help students in determining a career field in accordance with their potential to reach successful career. For this reason, it is necessary to develop proper and correct career planning before students directly work. As previously mentioned, it must be arranged based on their potential so there will be no conflict between their career and potential.

According to Piaget (Sciarra, 2004: 129), cognitive in adolescents is at the stage of formal thinking process. They have been able to use information to predict the effect of career decision making through their self- awareness.

Prising (2018) asserts that challenges and issues of current development including technology have become one of individual's needs to obtain the career. Companies require soft skill-based ability, techniques, and digital ability. Additionally, those requires the ability of self-identification of weakness and strength and the ability to improve digital leadership. For more, verbal and nonverbal ability as well as being able to collaborate and solve problems are also necessary to prepare career.

Abivian (2017) deems that there are many schools that have not applied career guidance which exactly affects students in determining their career. This is in line with the fact that
Guidance and Counseling (BK) teachers who experience obstacles to provide career group guidance service. Problems related to career for adolescents include selecting the type of education that leads to job selection, yet many counselors have not optimally provided career guidance service. Thus, it is necessary to renew career guidance

service that covers three aspects, namely planning, implementation, and evaluation (Lestari, 2017). Further, services should be life skills-based, so it can optimally foster students' knowledge, skills, values, and behavior. Later, they will be trained and accustomed with good behavior and skills in in carrying out their career. For more, Leksana (2013) mentions that innovation of career guidance service that is integrated with technology is necessary in order to create an interactive service. Rosqiyain \& Purwanta (2019) suggest that interactive media can be used in career guidance.

Regarding explanation above, a life skillbased career guidance model is urgently needed to develop and improve career planning. As a multimedia application, digital content can be used to deliver the guidance since it contributes to the development of learning media not only via computer, but also smartphone.

The career guidance provided in this study was life skill education-based digital content. It attempted to provided an understanding and description of students' selves as well as the definition of life skill education career with digital content. In the end, they would obtain an understanding and description of their career planning so they will be able to overcome problems in determining career options, especially to determine further education level after high school (SMA).

Based on the preliminary explanation, this study strived to examine the effectiveness of life skill education-based digital content to improve students' career planning. It was expected that this study can provide suggestion and ideas for counselors in providing career guidance to improve career planning in this pandemic COVID-19 era. 


\section{METHODS}

This study used one group pretest posttest that involved 150 students of grades XI and XII consisting of 52 male students and98 female students with age range of 16-18 years old.

The scale used was students career planning scale with indicators of recognizing personal characteristics, setting goals, assessing skills, and making career planning. The overall scales consist of 50 statements with four scale of career planning, namely ( $1=$ very inappropriate, $4=$ very appropriate). This scale has $\alpha$ coefficient of 0.83 .

Procedure introductory design with one group pretest posttest was employed by the researchers as the experimental design. The implementation of career guidance was carried out by distributing digital content guidance to students. Later, students logged in to careerplanning.web.id as student by entering Students Identification Number (NIS) and password that have been previously generated. When students opened the website, they should follow the guidance provided that was in accordance with their need. They needed 25 minutes of 45 minutes service times to learn digital content "Career Access Planning". One of digital content material displays accessed by student is presented in figure 1 .

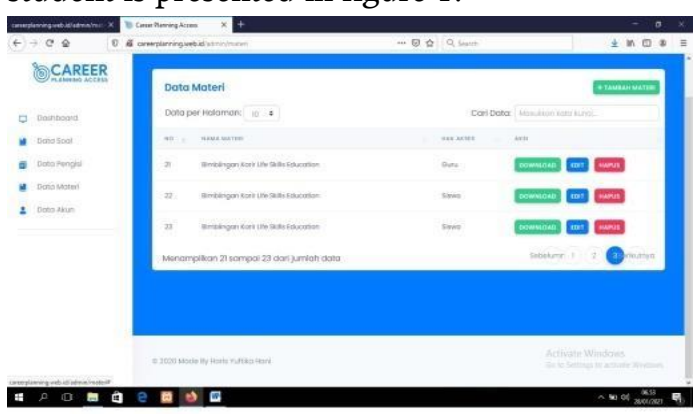

Figure 1. The Interface of Career Plaaning Material

\section{RESULTS AND DISCUSSION}

The level of career planning of 150 students quantitatively can be seen in table 1 . Based on the data before career guidance service given, there were 141 students (94\%) who had fair career planning, while the rest $(9$ students or
$6 \%$ had high career planning. On the contrary, after the service was given, 84 students $(56 \%)$ successfully had high career planning and 66 students (44\%) had moderate career planning.

Table 1. Students' Career Planning Level

\begin{tabular}{llll}
\hline & Category & $\mathrm{N}$ & $\%$ \\
\hline Pretest & High & 9 & $6 \%$ \\
& Fair & 141 & $94 \%$ \\
Posttest & High & 84 & $56 \%$ \\
& Fair & 66 & $44 \%$ \\
\hline
\end{tabular}

Table 2.Paired t-test Results

\begin{tabular}{lllll}
\hline & $\mathrm{M}$ & $\mathrm{SD}$ & $\mathrm{T}$ & $\mathrm{p}$ \\
\hline Pretest & 122.58 & 7.98 & -189.37 & $<0.01$ \\
\cline { 1 - 2 } Postest & 135.98 & 7.60 & & \\
\hline
\end{tabular}

As presented in Table 2, the paired t-test results showed an improvement of student's career planning after the life skill educationbased digital content career guidance was given $(\mathrm{t}=-189.37, \mathrm{p}<0.01)$. In other words, the guidance given effectively improved students career planning.

The implementation of classroom career guidance service with life skill education-based digital content was generally implemented through opening, core activities, and closing stage. It was expected that the career guidance with digital content that has been carried out was in tune with what Gysbers \& Henderson (2012) mention career guidance and counseling service is prepared as a systematic activity which supports students in understanding and making decision to develop the plans for their future. The important component in individual planning is counselors assessment. It aims to collect and interpret data related to students achievements, skills, interests, talents, and behavior. Later on, the data could be used as basis of decision making. Furthermore, counselors provided information that led to career awareness, self-knowledge, and skills in making decision and also simultaneously observed students' component (career exploration to improve career options), parental component (parents role in providing facilities as support for students career), and school 
personnel component (school programs integrated with subject teachers as support for students career). Lastly, placement and follow up helped students in the process of selecting position according to their skills, interest, and readiness to get structured work experiences.

Astuti \& Purwanta (2019) formulate the focus of individual planning consisting of first, academic aspect includes utilizing learning skills, making the right decision of education, major, or courses selection, and understanding the lifelong learning value. Second, career aspect covers exploring career opportunities and job training and understanding the needs for positive work habits. Third, personal - social aspect consists of positive self-concept and effective social skill development.

For more, Astuti \& Prwanta (2019) explain the implementation of technology in career guidance can be applied out through 1)

integrated career planning system, 2) social networking, and 3) mobile phone application. Accordingly, researchers arranged digital content to improve the ability of web and phone based career planning with hope that students were able to identify their career, motivated to develop career, able to get career information, and able to develop the right and appropriate career planning.

In the same way, life skill education was excessively important and effective to prevent problems that often arise including the use of illegal drugs, bullying and enhance adolescent self-confidence and self-esteem (Puspakumarag, 2013). Roodbari, Sahdipoor, \& Ghale (2013) suggest that life skill education has positive impacts on the increase of social, emotion, and social adjustment development. Moreover, it assists adolescents when facing dificulties or solving problems (Prajapati, Sharma, \& Sharma, 2017). Therefore, life skill education was significantly important to be taught to students through career guidance especially in career planning. Consequently, they would understand their ability and opportunities in the future with the right and appropriate career planning.

Career planning is conducted through several stages namely self-assessment, career opportunities investigation, setting goals, planning actions, and evaluating (Chetana \& Mohapatra, 2017). Basically, indiduals need to have skill to set plans since it can facilitate and maximize the process of decision making including career development. A planning process results options, evaluates options, makes decision, orginizes acts, and evaluates process. Hence, career planning is also influenced by individual internal process of life experiences so that it is necessary to be early established (Magnuson \& Starr, 2000). At last as the analysis results present, individual internal process also contributed to improve students career planning.

\section{CONCLUSION}

Considering the aim of this study, the implementation of career guidance service in SMA Negeri 1 Bulakamba is effective. Classroom career guidance service was chosen and developed with life skill education-based digital content. The criteria of this products are based on utility, feasibility, propriety, and accuracy, while the feasibility of criteria has been previously validated by media and career experts.

Life skill education-based career guidance service with digital content is positively able to improve students career planning. However, this study notices several weakness including students who do not have high learning motivation tend to failed, students' difficulty in accessing internet, especially during the pandemic with distance learning (PJJ), lack of mastering computer programming languages, and the tendency to ignore the academis or social aspects.

Under those circumstances, this study reccomends the implementation of effectiveness test with large subjects which later on are analyzed based on the use of android and computer. Besides, further researchers must find the relation with students psychology related to career planning. 


\section{REFERENCES}

Abivian, M., Budiamin, A., \& Agustin, M. (2017). Program bimbingan karir untuk mengembangkan kemampuan membuat pilihan karir peserta didik. Jurnal Kependidikan, 3 (1), 11-17

https://doi.org/10.37150/jut.v3i1.91

Astuti, B. \& Purwanta, E. (2019). Bimbingan karier untuk meningkatkan kesiapan karir. Yogyakarta: UNY Press.

Chetana, M. (2017). Career planning and career management as antecedents of career development: a study. Asian Journal of Management. 8(3), 614

Fajriah, U.N \& Sudarma, K. (2017). Pengaruh praktik kerja industry, motivasi memasuki dunia kerja dan bimbingan karir pada kesiapan kerja siswa. Economic Education Analysis Journal. 6 (2), 421432.

Gysbers. NC., \& Henderson, P. (2012). Developing and managing your school guidance and counseling program fifth edision. Vorwahl America Alexandria: American Counseling Assosiation.

Leksana, D. M., Mungin E.W., Imam T. (2013). Pengembangan modul bimbingan karir berbasis multimedia interaktif untuk meningkatkan kematangan karir siswa. Jurnal Bimbingan Konseling. 2(1), 1-9.

Lestari, I. (2017). Meningkatkan kematangan karir remaja melalui bimbingan karir berbasis life skills. Jurnal konseling GUSJIGANG.3 (1), 17-27.

Magnuson, Starr (2010). How early is too early to begin life career planning? the importance of the elementary school years. SAGE Journal. Volume 27, 2

Prajapti, Sharma, Sharma (2017). Significance of Life Skills Education. Volume 10 Number $1,1-6$

Prising, J. (2018). Skills Revolution 2.0: Robots Need Not Apply: Human Solutions for Skills Revolution. Manpowergroup.

Puspakumarag (2013). Effectiveness of life skills training program in preventing common issues among adolescents: a community based quasi experimental study (alst). Rajarata University: Srilanka, 1-26

Risqiyain, L.H \& Purwanta E. (2019). Pengembangan multimedia interaktif informasi karier untuk meningkatkan kematangan karir siswa Sekolah Menengah Kejuruan. Jurnal Kajian Bimbingan dan Konseling. 4(3), 88-93.

Roodbari, Sahdipoor, Ghale (2013), Effectiveness of life skills training program on assertiveness, stress management and interpersonal communication skills of adolescents in rural area. RR Juorna. 4, 331-334

Sugiyono. (2011). Metode Penelitian Kuantitatif, Kualitatif dan R \& D. Bandung: Alfabeta. Winkel, H. (2010). Bimbingan dan Konseling di Institusi Pendidikan. Yogyakarta: Media Abadi 